INTERNATIONAL JOURNAL OF MULTIDISCIPLINARY RESEARCh AND ANALySis

ISSN(print): 2643-9840, ISSN(online): 2643-9875

Volume 04 Issue 11 November 2021

DOI: 10.47191/ijmra/v4-i11-15, Impact Factor: 6.072

Page No.- 1588-1592

\title{
Lecturers Perception of Information and Communication Technology Skills Acquisition and Graduates Employability in Cross Rivers State, Nigeria
}

\author{
Nwosu, Patience Okwudiri ${ }^{1}$, Ogar, Joseph Ojishe ${ }^{2}$, Danjumam, John Salihu ${ }^{3}$ \\ ${ }_{1,3}$ Department of Educational Foundations, Taraba State University, Jalingo \\ ${ }^{2}$ Department of Educational Management, University of Calabar
}

\begin{abstract}
The advancement in technology and its dynamic influence on work processes puts high demand on ICT skills, thereby necessitating the need of students undertaking training in their respective fields of specializations to be more versatile in current labour market needs so as to be qualified to work in the ICT inclined labour market. The study examined Information and Communication technology skill acquisition and graduates' employability in Cross River State, Nigeria. Two research questions guided the study. Survey research design was adopted. The population of the study comprised of all the 475 lecturers in the Faculty of Education, University of Calabar. The simple random sampling technique was used to sample $47 \%$ resulting to 223 respondents. The instrument for data collection was a modified four point likert scale titled; information and communication technology skill acquisition and graduates employability questionnaire (ICTSAGEQ). The reliability estimate obtained using Cronbach alpha reliability was 0.85 . The data were analyzed using descriptive statistics of mean and standard deviation to answer research questions. Findings revealed that information and communication technology skill acquisition has significant influence on graduates' employability. The study further found that the challenges of ICT skills acquisition bothers around inadequate funding, inadequacy of ICT compliant manpower, poor power supply, lack of infrastructure among others. The study therefore concluded that ICT skill acquisition significantly influence graduates' employability in Cross River State, to this end, it was recommended that Students should be encouraged and sponsored to acquire relevant ICT skills before graduation to enable them fit into the modern world of work or possibly set up their personal ICT services for self -reliance and creating jobs for others thereby reducing unemployment and by extension youth restiveness.
\end{abstract}

KEY WORDS: Information, Communication, Technology, Skills, Graduates, Employability

\section{INTRODUCTION}

Employability deals with the possession of peculiar skills or requirements by an individual such as (as ability to carry out online marketing, programming, typesetting, good communication skills among others capable of making one employable by business enterprises or the world of work. Yorke and Knight (2004) asserted that employability is used to mean a set of achievements that comprise skills, understanding and personal attributes that make an individual more likely to secure and be successful in his/her chosen occupation to the benefit of him/herself, the workforce, the community and the economy. Employability is used to refer to the ability of an individual to gain employment appropriate to his/her educational standard (Dearing in Wickramasinghe \& Perera, 2010). Employability can be attributed to a broad range of skills that are needed in the world of work (Fulgence, 2016). In furtherance of this, employability attributes surpass just academic qualification, good communication skill and critical thinking but also competent knowledge of information and communication technology.

Information and communication technology to Raheen (2010) is the electronic pathways with viable communication devices like computers and other electronics. Technological innovation has impacted every aspect of human endeavour of which the world of work is an integral part of and its influence on the world of work has placed a high demand on Information and Communication Technology skills compared to other employability skills, hence necessitating the need to train students irrespective of their areas of specialty to be more versatile and updated with current trends on ICT skills that will make them meet up with labour market demands thereby making them fit to work in the sophisticated digital world of work. It is on this note Garrido (2011) posited that 


\section{Lecturers Perception of Information and Communication Technology Skills Acquisition and Graduates Employability in Cross Rivers State, Nigeria}

the current labour market considers ICT skills as highly relevant in recruitment processes for most of better jobs (Garrido et al 2011). He further asserted that ICT skills are considered an important asset which promotes competitiveness and improves business productivity. The importance of ICT skills is becoming more significant in sectors such as agriculture, construction, education and in the service industry. To give credence to the above, UNESCO (2012) categorically puts it that "gaining employment increasingly depends on person's ability to effectively and efficiently uses ICTs".

Employability skills focus on graduates' abilities to adapt and use their personal and academic skills to create more tangible educational outcomes that associate graduate employability with employment. It also refers the readiness of new graduates to contribute to their organisations in terms of skills, knowledge and attitude, as well as pragmatic industry understanding (Mason, Williams \& Crammer, 2006). Subsequently, it also relates to the ability of the graduates to be competent in soft skills (Ahmad, Mohd , Ismail \& Selamat, 2010). which could contribute to the graduates more likely to gain employment and be successful in their chosen occupations, which benefits themselves, the workforce, the community and the economy (Yorke and Knight, 2006). Not only that, the graduates are also required to be adaptable and flexible where they can easily learn, relearn and unlearn current and new knowledge to be able to make changes as required by the economic and technological environment at the time (Saad, Robani, Jano, \& Majid, 2014). They further stressed that employability can be observed in situations where new graduates are able to make themselves valuable to the organizations by possessing skills, knowledge and attitude relevant to the requirement of the organizations.

Ajibade (2009) asserts that there is a big gulf between what the school offer and the demand of employers. Ogundele (2010) opines that employers want employees who can use their abilities and skills to evolve the organization. In fact, there is no job that does not require its own skill for manpower development. The place of skill acquisition cannot be over emphasized in the rapid development of all sectors of the economy. Okoro in Ogundele, Feyisetan, and Shaaba, (2014) is of the view that our industries need skilled and well-trained workers to ensure that goods manufactured in Nigeria are as good as those manufactured in other parts of the world. No wonder most multinationals employ expatriates who possess the required skills to do the jobs at the expense of Nigerian graduates thereby weakening economic growth. For this situation to change, polices and goals on skill acquisition must be put in a place and well implemented.

Mustapha (2012) posited that employers in industries said that technical graduates in Malaysia have adequate technical skills, but they are still not satisfied with the communication and interpersonal skills, critical thinking, problem-solving and entrepreneurial skills possessed by those graduates. A range of empirical evidence exists indicating that employers are more inclined to hire graduates that possess both non-generic and technical skills. For example, Hagan when surveying 490 ICT firms in Australia found that $40 \%$ of these firms were not satisfied with the new graduates' business management skills and communication skills (Hagan, 2004). It was also reported that Japanese engineering graduates lack the initiative and problem-solving skills needed by the employers (Nguyen, Yoshinari, \& Shigeji, 2005). Similarly, Saad (2013) reported that whilst technical skills featured highly in the employability skills required from local engineering and ICT graduates, soft skills such problem-solving skills, communication skills, team working and leadership are also required from these graduates. To this end, it is worthy to state here that this study provides interesting pathway to understand the perception of lecturers towards ICT skills acquisition and graduates' employability.

Several studies established the relationship and effect of ICT skills on employability (Freeman, 2002 \& Organization for Economic Cooperation and Development, 2012). These studies indicated the way ICT transforms businesses and practices of enterprises across all sectors of the economy and also demonstrated new skills that are needed to exploit new ICT technologies and new innovations taking place in a "knowledge-based" world of work. These studies further unfold challenges facing graduates in the acquisition ICT skills demanded in all sectors of economic be more up to date; to possess adequate and relevant, skills and abilities that helps them handle sophisticated tools, machineries that are purely ICT operated, which were recently introduced as a result of ICT advancement. Although, these new jobs that require new competencies from workers are manifesting; the real creation of these jobs can only occur if the right mix of skills and competencies are available in the labour market (OECD, 2012).

\section{STATEMENT OF THE PROBLEM}

The unprecedented rate of unemployment facing the Nigerian society and most underdeveloped nations of the world is highly worrisome, this coupled with the bulk of graduates being turned out by higher institutions of learning on a yearly basis. Scholars and employers of labour in some economic climes have complained that these graduates not having the $21^{\text {st }}$ century skills (ICT), which is fundamental to thrive in modern world of work is devastating. This therefore calls for urgent attention to address it, else the grievous consequence of uncontrolled youths employment will be the order of the day with its attendant consequences such 


\section{Lecturers Perception of Information and Communication Technology Skills Acquisition and Graduates Employability in Cross Rivers State, Nigeria}

as armed robbery, terrorism, drug abuse and all other social vices capable of under developing the nation. It is to this end that this paper examined ICT skill acquisition and graduates employability in Cross River State and Nigeria as perceived by lecturers.

\section{PURPOSE OF THE STUDY}

The main purpose of this study was to examine acquisition of ICT skills and graduates' employability in Cross River. Specifically, the study sought to find out;

i. The influence of ICT skill acquisition on graduates' employability in Cross River State.

ii. The challenges of ICT skill acquisition in Cross River State.

\section{RESEARCH QUESTIONS}

1. How does the acquisition of ICT skills influence graduates' employability in Cross River State.?

2. What are the challenges of ICT skills acquisition in Cross River State.?

\section{METHODOLOGY}

The study adopted the descriptive survey design. The population of the study comprised of all the 475 lecturers in the faculty of education, University of Calabar. Proportionate random sampling technique was used for selecting a sample of $47 \%$ which resulted to two hundred and twenty- three (223) lecturers being sampled. Self-developed instrument was used for collect data titled "ICT Skills Acquisition and Graduates Employability Questionnaire (ICTSAGEQ)" which was contained fifteen (15) items part A measuring ICT skills acquisition while part B measured challenges facing the acquisition of ICT skills. The drafted instrument was presented to experts in fields of Educational Management and Educational Measurement and Evaluation, University of Calabar, for validation. Respondents were required to respond to the instrument using modified four point likert scale SA-Strongly Agree (4), A-Agree (3), SD-Strongly Disagree (2), D- Disagree (1) for positive items and the reverse for the negative items. In order to ascertain the reliability of the instrument, a trial test was conducted using 50 lecturers who were not part of the sample. Cronbach alpha reliability estimate of the instrument was done to determine the internal consistency of the items of the instrument. The result of the reliability estimate of the instrument was 0.85 which estimated reliable for the study. Descriptive statistics such as, mean and standard deviation were used to answer research questions. The decision benchmark was 2.50. this means that items that scored 2.50 and above are regarded as accepted while items with scores below 2.50 were rejected.

\section{RESULTS}

Research Question 1: How does the acquisition of ICT skills influence graduates' employability Table 1: Acquisition of ICT skills and graduates' employability

\begin{tabular}{llllll}
\hline S/N & \multicolumn{1}{c}{ ITEMS } & $\bar{X}$ & SD & \multicolumn{2}{l}{ DECISIONS } \\
\hline 1. & Equip graduates with data processing skills & & 2.71 & 1.234 & Agreed \\
2. & Equip graduates with skills for Packaging of innovations & 2.81 & 1.320 & Agreed & \\
3. Train graduates with skills for digital marketing & 2.51 & 0.972 & Agreed & \\
4. Train them for rendering of online services & & 2.58 & 0.983 & Agreed \\
5. Train graduates with digital communication skills & & 3.03 & 1.358 & Agreed \\
6. Equip graduates with data management skills & 2.57 & 0.951 & Agreed & \\
7. Inculcates in graduates' knowledge for peer tutorship & 2.53 & 1.441 & Agreed & \\
8. $\quad$ Equip graduate with programming skills & & 3.11 & \multicolumn{2}{c}{1.213} & Agreed
\end{tabular}

Results in table 1 revealed that respondents agreed to all items therein as ways acquisition of ICT skills influence graduates' employability. Specifically, the mean scores of 2.71, 2.81, 2.51, 2.58, 3.03, 2.57, 2.53 and 3.11 for items 1-8 which are all above 2.50 benchmark shows that acquisition of ICT skills influences graduates' employability.

Research Question 2: What are the challenges of ICT skills acquisition? 
Lecturers Perception of Information and Communication Technology Skills Acquisition and Graduates Employability in Cross Rivers State, Nigeria

Table 2: Challenges of ICT Skills Acquisition

\begin{tabular}{|c|c|c|c|c|c|}
\hline$S / N$ & Statements & $\bar{X}$ & SD & \multicolumn{2}{|c|}{ DECISIONS } \\
\hline 1. & Inadequate funding & & 3.02 & 1.358 & Agreed \\
\hline 2. & Inadequate competent manpower & 2.99 & \multicolumn{3}{|c|}{ Agreed } \\
\hline 3. & Lack of ICT equipment & 2.69 & \multirow[t]{2}{*}{1.104} & \multicolumn{2}{|c|}{ Agreed } \\
\hline 4. & Poor power supply & & & 1.104 & Agreed \\
\hline 5. & Cost of enrollment for ICT training & 2.82 & 1.187 & Agreed & \\
\hline 6. & Lack of ICT infrastructure & 2.99 & 0.863 & Agreed & \\
\hline 7. & Poor interest by graduates & 2.26 & 0.658 & Disag & greed \\
\hline
\end{tabular}

Results in table 2 shows that respondents agreed to items 1,2,3,4,5 and 6 therein as challenges of acquisition of ICT skill acquisition but disagreed on items 7 as not constituting a challenge to ICT skill acquisition with a mean score of 2.26 below 2.50 set as benchmark

\section{DISCUSSION}

The findings revealed that acquisition of ICT skills influence graduates' employability. This finding is in concord with Garrido (2011) who posited that the current labour market considers ICT skills as highly relevant in recruitment processes for most of better jobs. He further asserted that ICT skills are considered an important asset which promotes competitiveness and improves business productivity. The importance of ICT skills is becoming more significant in sectors such as agriculture, construction, education and in the service industry. To give credence to the above, UNESCO (2012) categorically puts it that "gaining employment increasingly depends on person's ability to effectively and efficiently uses ICTs".

On research question two, study established that inadequate funding, inadequate manpower, lack of ICT infrastructure, poor power supply among others ae the challenges of acquisition of ICT skills by graduates. This finding shares similitude with that of Scardamalia, and Bereiter, (2006) who asserted that it is quite unfortunate to have ICT skill centers without necessary during training facilities, trainees having little or no access to up-to-date machinery and equipment, trainers having demanded by present knowledge society and labour market.

\section{CONCLUSION}

It has been established that the acquisition of ICT skills enhances gradate employment chances in the modern day world of work. To this end, it is pertinent to state here that ICT is inevitable if one must be gainfully employed both in public and private organizations as findings showed that ICT skills are very essential requirement for employment and the challenges of ICT skill acquisition have also been identified for possible action

\section{RECOMMENDATION}

From the findings, the following recommendations are made

i. Students should be encouraged and sponsored to acquire relevant ICT skills before graduation to enable them fit into the modern world of work or possibly set up their personal ICT services for self -reliance and creating jobs for others thereby reducing unemployment.

ii. Government, private sector and philanthropists should as a matter of fact increase their commitment in supporting institutions of learning especially regarding provision of ICT infrastructures, power supply adequate and competent manpower to facilitate ICT skill acquisition so as to reduce the rate of unemployment and by extension youth restiveness.

\section{REFERENCE}

1) Ajibade, A, (2009). More graduates, less skills. Retrieved from http:// www.skill/com dated 30/11/2009.

2) Ahmad, S., Mohd Ishak, N., Ismail, K. \& Selamat, J., (2010). Generic competency profile among students in institute of higher learning: a case of Universiti Kebangsaan Malaysia (UKM), Malaysia. College Student J., 44, 3, 811-820

3) Fulgence, K. (2016). Employability of Higher Education Institution Graduates: Exploring the influence of Entrepreneurship Education and Employability Skills Development Programmes activities in Tanzania. 
4) Freeman, R.B., (2002). The labour market in the new information economy., National Bureau of Economic Research.

5) OECD, (2012). ICT Skills and Employment: New Competences and Jobs for a Greener and Smarter Economy. OECD Digital Economy Papers, No. 198, OECD Publishing.

6) Hagan, D. (2004). Employer Satisfaction with ICT Graduates. Proc. 6th Australasian Computing Educ. Conf.(ACE2004), Dunedin, New Zealand. CRPIT, 30. Lister, R. and Young, A.L. (Eds), ACS. 119-123).

7) Mason, G.W., Williams, G. \& Crammer, S.(2006). Employability skills initiatives in higher education: what effects do they have on graduate labour outcomes5 November 2014, http://www.hefce.ac.uk/pubs/rdreports/2003/rd13_03/default.asp

8) .Md Saad, M.S., Robani, A., Jano, Z. \& Ab. Majid, I. (2013). Employers' perception on engineering, information and communication technology (ICT) students' employability skills. Global J. of Engng. Educ., 15, 1, 42-47

9) Mushi, Renatus Michael (2020) "Assessment of the needs of ICT Skills on Employability in SMEs: A VFT approach," Journal of International Technology and Information Management: Vol. 29 : Iss. 1 , Article 4.

10) Mustapha, R., (2012). The Role of Vocational and Technical Education in the Industrialization of Malaysia as Perceived by Educators and Employers. Doctoral Thesis, Purdue University.

11) Nguyen, N.D., Yoshinari, Y. \& Shigeji, M. (2005). University education and employment in Japan: students'perceptions on employment attributes and implications for university education. Quality Assurance in Educ., 13, 3,202-218

12) Ogundele, A. G. (2010). Higher education and employability in the international labor market: the need for technical education. Retrieved from www.cefwa.net/compilation_for_proceedings.pdf - Nigeria.

13) Ogundele, A. G., Feyisetan, C. T. \& Shaaba, G. P. (2014). Technical education as a vital tool forskill acquisition through guidance and counselling for nation building. AmericanJournal of Educational Research, 2 (1), 50-53. doi: 10.12691/education-2-1-9.

14) Raheen, U.S. (2010). Information and Communication Technology as a means of achieving the objectives of vision 2020 in Nigeria. Journal of Education Review, 9: 9, 52-57.

15) Scardamalia, M. \& C. Bereiter, (2006). Knowledge building: Theory, pedagogy and technology. Th Cambridge handbook of the learning sciences

16) Wickramasinghe, V., \& Perera, L. (2010). Graduates', university lecturers' and employers' perceptions towards employability skills. Education+Training, 52(3), 226- 244.

17) Yorke, M. \& Knight P.T. (2004), Embedding employability into the curriculum. Learningand Employability Series, Retrieved March 05, 2005, from LTSN Generic Centre Web site:

http://www.heacademy.ac.uk/resources/publications/learningandemployability 